\title{
II. edukačně-odborná konference pracovní skupiny Ošetřovatelství České kardiologické společnosti
}

Za účasti 90 sester $\mathrm{z}$ různých oborů kardiologie - z nemocnic, ambulancí, Záchranné zdravotní služby Středočeského kraje a pozvaných hostů - uspořádala pracovní skupina Ošetřovatelství v kardiologii 1. listopadu 2008 II. edukačně-odbornou konferenci v Eiseltově sále 2. interní kliniky kardiologie a angiologie ve Všeobecné fakultní nemocnici a 1. lékařské fakultě Univerzity Karlovy v Praze.

$\mathrm{Na}$ programu konference se podílelo 17 přednášejících a spoluautorů ve čtyřech blocích.

Přednášejícím byla věnována nově vydaná publikace doc. E. Sovové a spol. Hypertenze pro praxi - pro lékaře, studenty, sestry, pacienty (Olomouc: Lékařská fakulta UP, 2008).

V prvním bloku zaujalo kasuistické sdělení V. Huňáčkové (Kardiologie na Bulovce, Praha) o drogově závislé nemocné. Seznámila přítomné s náročností léčby, ošetřrovatelskou péčí, ale i ekonomickou stránkou. Osud nemocné je nadále, i přes veškerou péči, nejistý po zdravotní i sociální stránce. V. Benešová (Kardiologie na Bulovce, Praha) se zabývala problematikou mitrální valvuloplastiky, a to etiologií, patofyziologií a vývojem vady, léčbou a prognózou nemocných na podkladě zkušeností, získaných na tomto pracovišti. Př́iprava a zajištění elektrické kardioverze u nemocných s poruchami srdečního rytmu bylo předmětem sdělení $P$. Neubauerové (Kardiologie na Bulovce, Praha). P. Vrbenská (2. interní klinika kardiologie a angiologie, VFN, Praha) nazvala svou přednášku „Jaké jsou možnosti péče o nemocného se subakutním infarktem myokardu, komplikovaným kardiogenním šokem, a na čem závisí úspěšnost.“ Upozornila na nové léčebné postupy, technické vybavení a vzdělávání $\mathrm{v}$ problematice, které značnou měrou rozhodují o úspěšnosti.

Druhý blok zahájil J. Neumann ze společnosti SestraIN informacemi o možnostech a výhodách internetové učebny v rámci celoživotního vzdělávání. Vyzval přítomné, aby se zapojili do této činnosti. V kardiologii spatřuje velký potenciál, který by rozšíril jejich programovou nabídku a současně přispěl k prohlubování znalostí z různých disciplín ošetřovatelství v kardiologii. M. Křečková (2. interní klinika kardiologie a angiologie, VFN, Praha) hovořila o úloze sestry v ambulanci srdečního selhání. Využití různých didaktických pomůcek je nezbytností. Ověrování, zda nemocný porozuměl režimovým opatřením, je nutností pro úspěšnou spolupráci. Prospěšné je také zapojení nejbližších členů rodiny.

K. Malá (Interní oddělení s jednotkou intenzivní péče, ÚVN, Praha) seznámila př́tomné se stavem příprav standard ošetřovatelství v kardiologii. Standardy byly v řadě větších nemocnic již vytvořeny a využívají se. Je otázkou, zda vypracovat obecně platné standardy, které by byly návodem i pro další kardiologická pracoviště. Nabízí se vypracování ošetřovatelských postupů u různých stavů, napr. u akutního koronárního syndromu, akutního/chronického srdečního selhání apod.

E. Sovová (I. interní klinika, FN Olomouc a LF UP) ukázala na prevenci v kardiologii z pohledu „Popelky“ nebo „Chytré horákyně." Vycházela při tom $\mathrm{z}$ projektů realizovaných v Olomouci. Pokud se prevence nestane celostátním programem, který by měl jednotná pravidla, a nebude podporován zdravotní politikou státu, nebude mít dostatečnou účinnost a tudíž bude i nadále „Popelkou.“ Můžeme poděkovat nadšencům, kteří projekty úspěšně realizují v několika lokalitách České republiky.

Třetí blok byl zaměřen na předcházející a budoucí aktivity PSOK. J. Leso (předseda PSOK ČKS) seznámil přítomné s historií, cíli, vizemi a aktivitami činnosti pracovní skupiny. Vyzval $\mathrm{k}$ součinnosti všechny sestry $\mathrm{v}$ oboru ošetřovatelství v kardiologii na postupné realizaci programů. Výbor ČKS je průběžně seznamován s činností skupiny. Na říjnové schůzi ČKS bylo vyhověno požadavku na úpravu členských stanov. Vyplývá z toho, že sestry, které budou mít zájem o akce $\mathrm{v}$ zahraničí pořádané CCNAP ESC (Council on Cardiovascular Nursing and Allied Profession European Society of Cardiology) získají finanční podporu výboru ČKS při aktivní účasti. Doposud to bylo umožněno jen lékařům do 35 let. Bližší podrobnosti lze nalézt na webových stránkách ČKS, které je vhodné pravidelně sledovat.

T. Pečánková, první sestra, která byla zvolena do struktur CCNAP ESC v červnu minulého roku (do edukační komise), seznámila přítomné se záměry této komise. Podrobnější informace poskytne po jednání na „Jarním kongresu CCNAP ESC v Dublinu“, kterého se zúčastní.

L. Šedová (Jihočeská univerzita, České Budějovice) uvedla výsledky grantového projektu z oblasti preventivní kardiologie na téma „Pacienti s ischemickou chorobou srdeční.“ Jedná se o jednu z oblastí, kde sestry mohou své znalosti a zkušenosti uplatnit. V letošním roce byl vyhlášen projekt podobného zaměření $\mathrm{v}$ rámci CCNAP ESC. Bohužel na tento grantový projekt se nepřihlásilo žádné pracoviště $\mathrm{z}$ naší republiky (poznámka autora).

T. Hess (Kardiocentrum, Liberec) seznámil přítomné s novým systémem přenosu patofyziologických dat o pacientovi mezi členy Rychlé záchranné služby a Kardiocentrem v krajské nemocnici. Již relativně krátká doba jeho použití prokázala význam při rozhodování o osudu nemocných s akutním koronárním syndromem.

J. Mrňáková (Kardiocentrum KJ, Liberec) hovořila o zkušenostech s používáním neinvazivní umělé plicní ventilace na koronární jednotce. Názorně ukázala aplikaci speciální obličejové masky. Upozornila, za jakých okolností ji lze použít, a jaké jsou limitace této metody. 
Čtvrtý blok přinesl řadu novinek a zajímavostí z terénní akutní medicíny, a to díky pozvaným zástupcům ze Záchranné zdravotní služby Středočeského kraje - P. Tomáše, J. Callerové a R. Škulce. Sdělení o „ABC resuscitaci“ v roce 2008 představovalo bohatou paletu zkušeností, postřehů a kasuistik z terénní praxe v podání $\mathrm{P}$. Tomáše. Upozornil na nutnost soustavného tréninku v resuscitaci na všech kardiologických pracovištích. Podrobné informace o $\mathrm{ABC}$ resuscitaci lze nalézt na webových stránkách: www.zachrannasluzba.cz.

R. Škulec informoval o současném stavu metody mírné hypotermie po srdeční zástavě. Po teoretickém úvodu do metody představil na skutečných př́padech řešení život ohrožující stavů. J. Callerová hovořila $\mathrm{z}$ pohledu sestry o mírné hypotermii v přednemocniční péči a její návaznosti na nemocniční péči, doloženou několika konkrétními př́ípady.

V posledním sdělení konference se zabývala J. Najmanová (IKEM, Praha) ošetřovatelskou péčí u nemocných s transplantovaným srdcem. Upozornila na řadu klíčových momentů, které jsou předpokladem úspěchu léčby $\mathrm{v}$ pooperačním období a právnické aspekty dárcovství orgánů.

$\mathrm{Na}$ závěr konference poděkoval předseda PSOK J. Leso přednášejícím za kvalitu a odbornou náplň sdělení, za zájem a diskusní př́spěvky přítomných. Současně pozval všechny sestry na další akce PSOK ČKS v roce 2009:

> Jarní konference v Praze (duben)

> XVII. sjezd ČKS v Brně (květen)

> III. edukačně-odborná konference (listopad)

Bližší údaje o těchto akcích budou zveřejněny v Cor et Vasa a na webové stránce ČKS (www.kardio-cz.cz).

Poděkování za podporu při realizaci konference společnostem: AstraZeneca, Servier, Zentiva a redakci časopisu Diagnóza.

MUDr. Jiř́ Leso,

předseda pracovní skupiny Ošetřovatelství ČKS,

e-mail:leso@mnnp.cz 